\title{
Acute cardiovascular effects of controlled exposure to dilute Petrodiesel and biodiesel exhaust in healthy volunteers: a crossover study
}

Jon Unosson ${ }^{1,2}$, Mikael Kabéle ${ }^{1}$, Christoffer Boman³ ${ }^{3}$ Robin Nyström³ ${ }^{3}$ loannis Sadiktsis ${ }^{4}$, Roger Westerholm ${ }^{4}$, lan S. Mudway ${ }^{5}$, Esme Purdie ${ }^{5}$, Jennifer Raftis ${ }^{6}$, Mark R. Miller ${ }^{7}$, Nicholas L. Mills ${ }^{7,8}$, David E. Newby ${ }^{7}$, Anders Blomberg ${ }^{1}$, Thomas Sandström ${ }^{1,9^{*}}$ (D) and Jenny A. Bosson ${ }^{1}$

\begin{abstract}
Background: Air pollution derived from combustion is associated with considerable cardiorespiratory morbidity and mortality in addition to environmental effects. Replacing petrodiesel with biodiesel may have ecological benefits, but impacts on human health remain unquantified.

The objective was to compare acute cardiovascular effects of blended and pure biodiesel exhaust exposure against known adverse effects of petrodiesel exhaust (PDE) exposure in human subjects.

In two randomized controlled double-blind crossover studies, healthy volunteers were exposed to PDE or biodiesel exhaust for one hour. In study one, 16 subjects were exposed, on separate occasions, to PDE and 30\% rapeseed methyl ester biodiesel blend (RME30) exhaust, aiming at $\mathrm{PM}_{10} 300 \mathrm{\mu g} / \mathrm{m}^{3}$. In study two, 19 male subjects were separately exposed to PDE and exhaust from a 100\% RME fuel (RME100) using similar engine load and exhaust dilution. Generated exhaust was analyzed for physicochemical composition and oxidative potential. Following exposure, vascular endothelial function was assessed using forearm venous occlusion plethysmography and ex vivo thrombus formation was assessed using a Badimon chamber model of acute arterial injury. Biomarkers of inflammation, platelet activation and fibrinolysis were measured in the blood.

(Continued on next page)
\end{abstract}

\footnotetext{
* Correspondence: thomas.sandstrom@lung.umu.se

'Department of Public Health and Clinical Medicine, Section of Medicine, Umeå University, Umeå, Sweden

${ }^{9}$ Dept. of Medicine, Division of Respiratory Med, University Hospital, 90185 Umeå, Sweden

Full list of author information is available at the end of the article
}

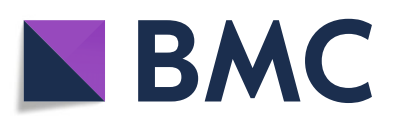

(c) The Author(s). 2021 Open Access This article is licensed under a Creative Commons Attribution 4.0 International License, which permits use, sharing, adaptation, distribution and reproduction in any medium or format, as long as you give appropriate credit to the original author(s) and the source, provide a link to the Creative Commons licence, and indicate if changes were made. The images or other third party material in this article are included in the article's Creative Commons licence, unless indicated otherwise in a credit line to the material. If material is not included in the article's Creative Commons licence and your intended use is not permitted by statutory regulation or exceeds the permitted use, you will need to obtain permission directly from the copyright holder. To view a copy of this licence, visit http://creativecommons.org/licenses/by/4.0/ The Creative Commons Public Domain Dedication waiver (http://creativecommons.org/publicdomain/zero/1.0/) applies to the data made available in this article, unless otherwise stated in a credit line to the data. 
(Continued from previous page)

Results: In study 1, PDE and RME30 exposures were at comparable PM levels $\left(314 \pm 27 \mu \mathrm{g} / \mathrm{m}^{3} ;(\right.$ PM $10 \pm$ SD) and $309 \pm 30 \mu \mathrm{g} / \mathrm{m}^{3}$ respectively), whereas in study 2, the PDE exposure concentrations remained similar (310 $\pm 34 \mu \mathrm{g} /$ $\left.\mathrm{m}^{3}\right)$, but RME100 levels were lower in PM $\left(165 \pm 16 \mu \mathrm{g} / \mathrm{m}^{3}\right)$ and PAHs, but higher in particle number concentration. Compared to PDE, PM from RME had less oxidative potential. Forearm infusion of the vasodilators acetylcholine, bradykinin, sodium nitroprusside and verapamil resulted in dose-dependent increases in blood flow after all exposures. Vasodilatation and ex vivo thrombus formation were similar following exposure to exhaust from petrodiesel and the two biodiesel formulations (RME30 and RME100). There were no significant differences in blood biomarkers or exhaled nitric oxide levels between exposures.

Conclusions: Despite differences in PM composition and particle reactivity, controlled exposure to biodiesel exhaust was associated with similar cardiovascular effects to PDE. We suggest that the potential adverse health effects of biodiesel fuel emissions should be taken into account when evaluating future fuel policies.

Trial registration: ClinicalTrials.gov, NCT01337882/NCT01883466. Date of first enrollment March 11, 2011, registered April 19, 2011, i.e. retrospectively registered.

Keywords: Air pollution, Particulate matter, Diesel, Biodiesel, Cardiovascular system, Vascular function, Vasomotor dysfunction, Thrombosis, Endothelial function

\section{Background}

Particulate matter air pollution (PM) has a well-established and consistent association with cardiovascular and respiratory morbidity and mortality [1-3]. This link has proven strongest for fine combustion-derived PM (particle diameter $<2.5 \mu \mathrm{m} ; \mathrm{PM}_{2.5}$ ) [4]. Exhaust from diesel engines is an important contributor to $\mathrm{PM}_{2.5}$ in urban environments, as well as being a major source of smaller combustion-derived nanoparticles [5]. Time in traffic has been associated with triggering of acute myocardial infarction [6] and there is a wealth of data from controlled human experimental exposure studies showing that petrodiesel exhaust (PDE) has multiple adverse effects throughout the cardiovascular system [7-10].

Due to adverse environmental effects of fossil fuels, considerable efforts have been made to find alternative renewable energy sources. The European Union has a current target for $10 \%$ use of biofuels within transportation (EU Directive 2009/28/EC), Finland targets 30\% biofuel by 2030 [11] and similar efforts are planned in the US, China, India and elsewhere [12].

The ideal biofuel would be cheap to produce, compatible with existing infrastructure and engine technologies, but, importantly, would not cause harm to either human health or the environment [13]. Biodiesel (diesel fuel made from biological substances rather than petroleum sources) meets several of these criteria and, as a result, it is increasingly added to petrodiesel used in commercial and industrial settings $[14,15]$.

Untreated oils from vegetables and plants are not suitable to run in modern diesel engines without a transesterification process. When rapeseed oil is used, the end product is rapeseed methyl ester (RME), which has good ignition and lubrication properties. RME is popular in Europe as it can be produced locally, blended into petrodiesel and used in existing diesel engines. Novel production methods of biodiesel are being developed to decrease land usage and increase yield, however, currently rapeseed and soybean are the major crops for biodiesel production in Europe and the US, respectively.

While the efficiency of biofuel combustion has been wellstudied, relatively little focus has been directed towards the health effects of emissions generated from biofuels, despite the rapid introduction of these fuels in societies and calls for such research $[14,16]$. Several in vitro studies and animal studies have addressed the potential health effects of biodiesel exhaust exposure [17-19], but, to our knowledge, there is only one human exposure study in a mining environment reporting on respiratory and peripheral blood inflammatory markers [20].

In the present study, we assessed the potential acute vascular and thrombotic effects of replacing petrodiesel with a $30 \%$ or $100 \%$ rapeseed biodiesel formulation, following controlled exposure in young healthy volunteers. It was hypothesized that inhalation of exhaust from biodiesel formulations would induce lesser cardiovascular effects compared to standard petrodiesel fuel.

\section{Results}

Sixteen subjects completed study one (RME30 vs. PDE exposure and 19 subjects completed study two (RME100 vs. PDE exposure) (Table 1). The studies were well tolerated by all subjects with no adverse events. There were no significant differences in lung function measured as $\mathrm{VC}$ and $\mathrm{FEV}_{1}$ pre vs. post exposure (data not shown).

\section{Exposures}

In study one (RME30 vs. PDE), the comparison aimed at a target concentration in the exposure chamber of $\mathrm{PM}_{2.5}$ $300 \mu \mathrm{g} / \mathrm{m}^{3}$ for both fuel types. To account for the 
Table 1 Subject characteristics

\begin{tabular}{|c|c|c|c|c|}
\hline Parameter & \multicolumn{2}{|c|}{ Study one, $n=16,2$ females. } & \multicolumn{2}{|c|}{ Study two, $n=19$, all males } \\
\hline Age, years & \multicolumn{2}{|l|}{$25(21-29)$} & \multicolumn{2}{|l|}{$28(20-38)$} \\
\hline Height, cm & \multicolumn{2}{|c|}{$\begin{array}{l}\text { Males: } 181 \text { (173-195) } \\
\text { Females: } 171 \text { (166-176.5) }\end{array}$} & \multicolumn{2}{|l|}{$181(168-190)$} \\
\hline Weight, kg & \multicolumn{2}{|c|}{$\begin{array}{l}\text { Males: } 75 \text { (67-88) } \\
\text { Females: } 69(60-79)\end{array}$} & \multicolumn{2}{|l|}{$79(55-97)$} \\
\hline BMI, $\mathrm{kg} / \mathrm{m}^{2}$ & \multicolumn{2}{|c|}{$\begin{array}{l}\text { Males: } 23(20-25) \\
\text { Females: } 23(21-25)\end{array}$} & \multicolumn{2}{|l|}{$24(19-29)$} \\
\hline Pre exposure measures & Petrodiesel & RME30 & Petrodiesel & RME100 \\
\hline Vital capacity, L & $5.8 \pm 0.3$ & $5.9 \pm 0.3$ & $6.3 \pm 0.3$ & $6.3 \pm 0.3$ \\
\hline $\mathrm{FEV}_{1}, \mathrm{~L}$ & $4.6 \pm 0.2$ & $4.6 \pm 0.2$ & $4.8 \pm 0.2$ & $4.8 \pm 0.2$ \\
\hline $\mathrm{FE}_{\mathrm{NO}} 50, \mathrm{ppb}$ & $12 \pm 1$ & $11 \pm 1$ & $13 \pm 1$ & $15 \pm 2$ \\
\hline Systolic blood pressure, $\mathrm{mm}$ hg & $121 \pm 3$ & $123 \pm 2$ & $136 \pm 3$ & $135 \pm 3$ \\
\hline Diastolic blood pressure, $\mathrm{mm}$ hg & $69 \pm 1$ & $71 \pm 1$ & $79 \pm 2$ & $78 \pm 2$ \\
\hline Heart rate, bpm & $65 \pm 2$ & $64 \pm 2$ & $68 \pm 2$ & $67 \pm 2$ \\
\hline Hemoglobin, $\mathrm{g} / \mathrm{L}$ & $148 \pm 3$ & $147 \pm 3$ & $151 \pm 2$ & $151 \pm 2$ \\
\hline Leukocyte particle concentration $\times 10^{9} / \mathrm{L}$ & $5.7 \pm 0.3$ & $5.7 \pm 0.4$ & $5.4 \pm 0.2$ & $5.5 \pm 0.3$ \\
\hline Platelet concentration, $\times 10^{9} / \mathrm{L}$ & $231 \pm 11$ & $236 \pm 11$ & $232 \pm 11$ & $230 \pm 10$ \\
\hline Lymphocytes, $\times 10^{9} / \mathrm{L}$ & $2.1 \pm 0.2$ & $2.1 \pm 0.2$ & $2.2 \pm 0.2$ & $2.2 \pm 0.2$ \\
\hline Monocytes, $\times 10^{9} / \mathrm{L}$ & $0.5 \pm 0.0$ & $0.5 \pm 0.0$ & $0.5 \pm 0.0$ & $0.5 \pm 0.0$ \\
\hline Neutrophils, $\times 10^{9} / \mathrm{L}$ & $2.9 \pm 0.2$ & $3.0 \pm 0.2$ & $2.6 \pm 0.1$ & $2.6 \pm 0.2$ \\
\hline
\end{tabular}

Median and range for anthropomorphic measures. Mean \pm standard error of the mean (SEM) for pre-exposure baseline cardiorespiratory and hematological measures

commonly observed lower PM mass emissions of biodiesel, study 2 (RME100 vs. PDE) was not designed for equal PM mass concentrations in the exposure chamber. Rather, the RME100 exposure was using similar engine and exhaust dilution settings as the PDE exposure (aimed at $\mathrm{PM}_{10} 300 \mu \mathrm{g} / \mathrm{m}^{3}$ ), which resulted in lower mass emissions of RME100 PM.

Basic characterization of RME30 exhaust was relatively similar to that of PDE, as regards $\mathrm{PM}_{10}$, total hydrocarbons and elemental carbon/organic carbon ratio (EC/OC ratio) (Table 2). Compared to PDE, RME100 exhaust contained more and smaller particles. (Table 2, Fig. 1). RME100 exhaust particles had a lower EC/OC ratio and less particle-bound polycyclic aromatic hydrocarbons (PAHs), as compared with PDE. The gas phase of RME30 and RME100 exhaust contained higher concentrations of NOx than PDE. The fact that NOx differed slightly between RME exposures, was due to minor tuning issues required by the engineers managing the exposure set up.

The oxidative potential (OP) of PM measured with electron paramagnetic resonance (EPR) showed a lower oxidative potential with increasing RME content within the fuel. The RME100 fuel sample generated significantly less superoxide free radicals per mass of PM than the petrodiesel or RME30 (Fig. 2). Oxidative potential (OP) was also measured by the quantification of antioxidant losses from a synthetic respiratory tract lining fluid. This generated two metrics, based on ascorbate and glutathione oxidative consumption over a 4-h incubation period, $\mathrm{OP}^{\mathrm{AA}}$ and $\mathrm{OP}^{\mathrm{GSH}}$ respectively, expressed per unit mass $(\mu \mathrm{g})$ of extracted PM. These data are illustrated in Fig. 2, panel a, for each fuel type and for the individual $<0.2$ and $0.2-0.5 \mu \mathrm{m}$ fractions. To allow comparison with the EPR data, the $\mathrm{OP}^{\mathrm{AA}}$ and $\mathrm{OP}^{\mathrm{GSH}}$ values have been aggregated to provide a total oxidative potential $\left(\mathrm{OP}^{\mathrm{TOT}}\right)$ across both fractions, which was equivalent to the sample employed for the EPR analysis. This composite measure of oxidative potential showed a similar overall pattern to that observed by EPR, with decreasing activity as the proportion of RME increased. The individual ascorbate and glutathione dependent OPs provided a less coherent pattern, with RME 100 having the lowest $\mathrm{OP}^{\mathrm{AA}}$ and RME30 the lowest $\mathrm{OP}^{\mathrm{GSH}}$ activities.

Of the metals considered, there were significantly higher levels of manganese $(\mathrm{Mn})$, iron $(\mathrm{Fe})$, vanadium $(\mathrm{V})$, nickel $(\mathrm{Ni})$, chromium $(\mathrm{Cr})$ and molybdenum $(\mathrm{Mo})$ in the RME30 blend and pure RME100, relative to the $\mathrm{PDE}$ in both the $\mathrm{PM}_{<0.2} \mu \mathrm{m}$ and $\mathrm{PM}_{0.2-0.5} \mu \mathrm{m}$ size ranges (Fig. 2, panel b). The concentrations of the remaining metals/metalloids measured in each fuel fraction are summarised in Supplementary Table S1.

\section{Vascular and thrombosis studies}

Plethysmographic data and net t-PA release were determined as described previously [21, 22]. Infusion of all 
Table 2 Exposure characteristics

\begin{tabular}{|c|c|c|c|c|}
\hline & \multicolumn{2}{|l|}{ Study one } & \multicolumn{2}{|l|}{ Study two } \\
\hline & Petrodiesel & RME30 & Petrodiesel & RME100 \\
\hline $\mathrm{PM}_{10}, \mu \mathrm{g} / \mathrm{m}^{3}$ & $314 \pm 27$ & $309 \pm 30$ & $310 \pm 34$ & $165 \pm 16$ \\
\hline Total Hydrocarbons, ppm & $1.0 \pm 0.1$ & $0.9 \pm 0.1$ & $0.9 \pm 0.2$ & $0.9 \pm 0.2$ \\
\hline $\mathrm{NO}_{\mathrm{x}}, \mathrm{ppm}$ & $3.9 \pm 1.0$ & $4.6 \pm 1.0$ & $6.1 \pm 0.4$ & $7.3 \pm 0.5$ \\
\hline $\mathrm{NO}_{2}, \mathrm{ppm}$ & $0.7 \pm 0.1$ & $0.3 \pm 0.1$ & $0.4 \pm 0.1$ & $0.5 \pm 0.1$ \\
\hline Temp, C & $22 \pm 1$ & $22 \pm 1$ & $22 \pm 2$ & $22 \pm 1$ \\
\hline Relative humidity, \% & $36 \pm 13$ & $33 \pm 11$ & $28 \pm 11$ & $30 \pm 13$ \\
\hline Particle number concentration $\times 10^{5} / \mathrm{cm}^{3}$ & $\mathrm{n} / \mathrm{a}$ & $\mathrm{n} / \mathrm{a}$ & $1.7 \pm 3.2$ & $2.2 \pm 1.4$ \\
\hline $\mathrm{EC} / \mathrm{OC}$, ratio* & $0.66 \pm 0.01$ & $0.64 \pm 0.02$ & $n / d$ & $0.43 \pm 0.03$ \\
\hline Particle bound PAHs, $\mathrm{ng} / \mathrm{m}^{3}$ & $156 \pm 16$ & $127 \pm 15$ & $n / d$ & $76 \pm 24$ \\
\hline Semi volatile PAHs, $\mathrm{ng} / \mathrm{m}^{3}$ & $244 \pm 81$ & $158 \pm 37$ & $n / d$ & $225 \pm 167$ \\
\hline
\end{tabular}

vasodilators generated a dose-dependent increase in forearm blood flow (2-way ANOVA for incremental doses of acetylcholine, bradykinin, sodium nitroprusside and verapamil, $p<0.05$ for all drugs following all exposures). The vasodilatation was similar in both studies comparing responses for the respective agonists following PDE vs. RME30 (Study $1 ; n=15$ ) and PDE vs. RME100 (Study 2; $n=18$ ) (2-way ANOVA comparing each drug in incremental doses following respective exposure; $p>0.05$ for all, Fig. 3. A filtered air arm could not be included in the present study, due to the extensive logistical aspects of mounting three-arms studies with bilateral arm canulations and infusions. However, the consistent and very repeatable attenuation of vasodilatation by PDE vs. filtered air, based on pooled

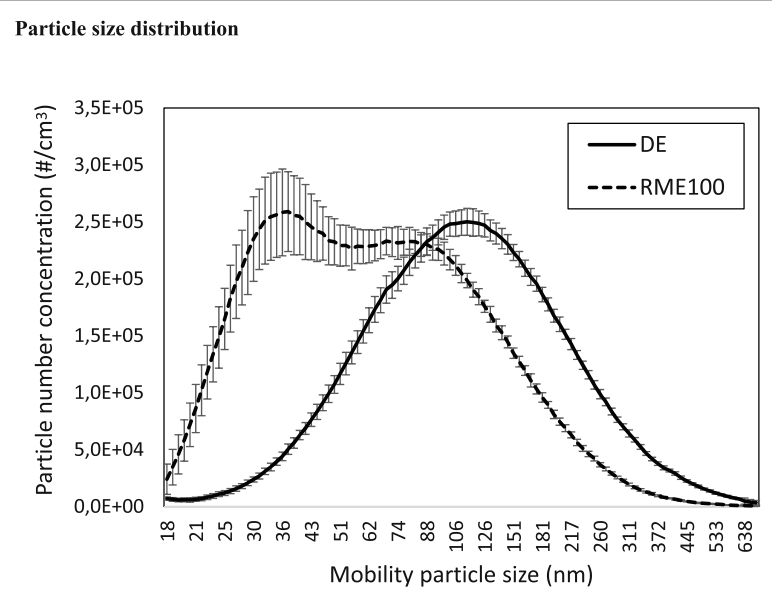

Fig. 1 Particle size distribution during PDE and RME100 exhaust exposure. Mean with standard deviation. Exposures were kept constant and measurements $(n=3)$ were spread out over the exposure series historical data from four studies [23-26] is given in Fig. $\mathrm{S} 1$ in the supplement.

In both studies, ex vivo thrombus formation was similar following all exposures with mean total thrombus area in the perfusion chamber being 10,192 (95\% CI [7718, 12,665]) $\mu \mathrm{m}^{2}$ following PDE and 10,888 (95\% CI $[8815,12,922]) \mu \mathrm{m}^{2}$ following RME30 exhaust in study one $(n=13)$, and $8973(95 \%$ CI $[8175,9771]) \mu \mathrm{m}^{2}$ following PDE and 9424 (95\% CI $[8194,10,654]) \mu \mathrm{m}^{2}$ following RME100 exhaust in study two $(n=19)(p=0.37$ and 0.48 , respectively, Fig. 4).

In both studies, mean plasma t-PA antigen concentrations were similar after all exposures, with 4.9 (95\% CI $[3.7,6.1]) \mathrm{ng} / \mathrm{mL}$ following PDE and 4.7 (95\% CI [3.4, 5.9]) $\mathrm{ng} / \mathrm{mL}$ following RME30 exhaust in study one $(n=$ 14), and 5.2 (95\% CI $[4.0,6.4]) \mathrm{ng} / \mathrm{mL}$ following PDE and 6.3 (95\% CI $[4.5,8.2]) \mathrm{ng} / \mathrm{mL}$ following RME100 exhaust in study two $(n=17)$ (Fig. 5 , left panel). Bradykinin infusion caused a dose dependent release of t-PA that was similar following all exposures to PDE and RME, with no significant differences between the paired exposure scenarios $(p=0.43$ for PDE vs. RME30 and $p=0.35$ for PDE vs. RME100; 2-way ANOVA) (Fig. 5, right panel).

\section{Blood cell counts and platelet activation}

There was a similar ( $p>0.05$ for all) transient rise in neutrophils following all exposures, that had returned to baseline by $24 \mathrm{~h}$ post exposure (Supplement Table S2). However, there were no differences between exposures. Mean platelet activation did not differ between exposures, with mean platelet CD40 ligand and P-selectin expression and platelet-monocyte binding all being similar at 2 and $4 \mathrm{~h}$ post exposure, ( $\mathrm{p}>0.05$ for all, Supplement Table S3). 


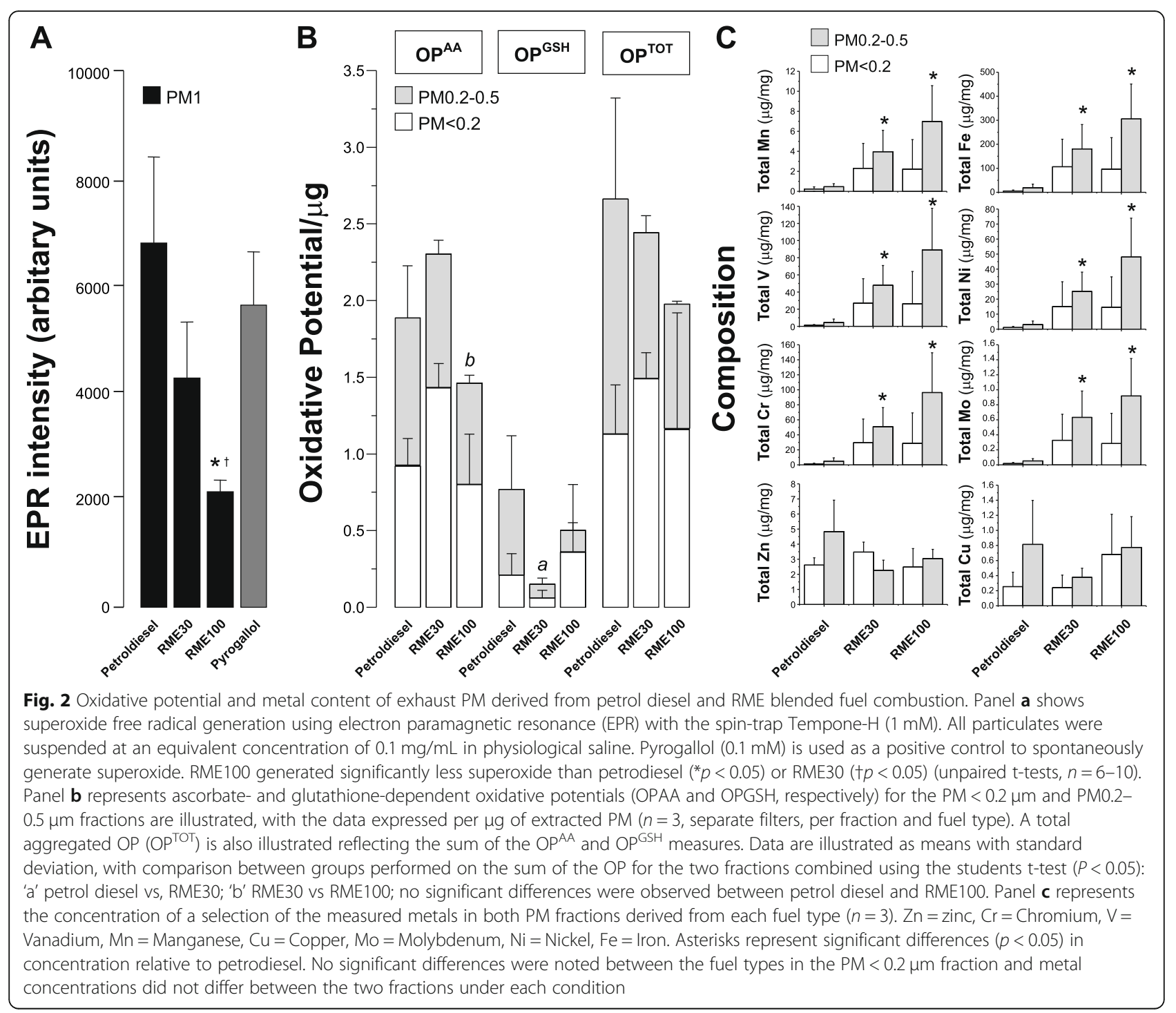

\section{Fraction of exhaled NO}

There were no significant changes in $\mathrm{FE}_{\mathrm{NO}} 50$ following exposures or differences comparing respective exposures (Supplement Table S4).

\section{Discussion}

To our knowledge, this study represents the first detailed investigation of the impact of biodiesel exhaust emissions on functional cardiovascular endpoints (vasomotion, thrombus formation, fibrinolytic markers, platelet function and blood cell differential including inflammatory cells) in healthy human volunteers. The study also performed a detailed characterization of the tail-pipe emissions, with physiochemical profiling of the PM within the exhaust. We have shown that, despite chemical and physical differences, the acute effects of biodiesel exhaust inhalation on thrombus formation and the vascular system were similar to those observed upon PDE exposure.

Numerous controlled experimental exposures studies in human volunteers have shown that exposure to PDE causes acute cardiovascular and respiratory effects. Acute exposure has consistently been shown to induce endothelial dysfunction, in terms of impaired vasomotor function and endogenous fibrinolysis [7, 8, 23-25, 27]. Inhalation of PDE also induces thrombus formation $[8$, 23, 26] platelet activation [7, 8, 23], arterial stiffness [9] as well as systemic and airway inflammation [20, 28-31]. Exposure to fine PM of concentrated ambient urban particles (CAPs) has also been found to increase blood pressure and arterial vasoconstriction [32].

The vascular effects of PDE compared with filtered air exposures have been highly consistent in previous studies from our group. Specifically, when compared with filtered air exposures, PDE exposures have resulted in 
A.
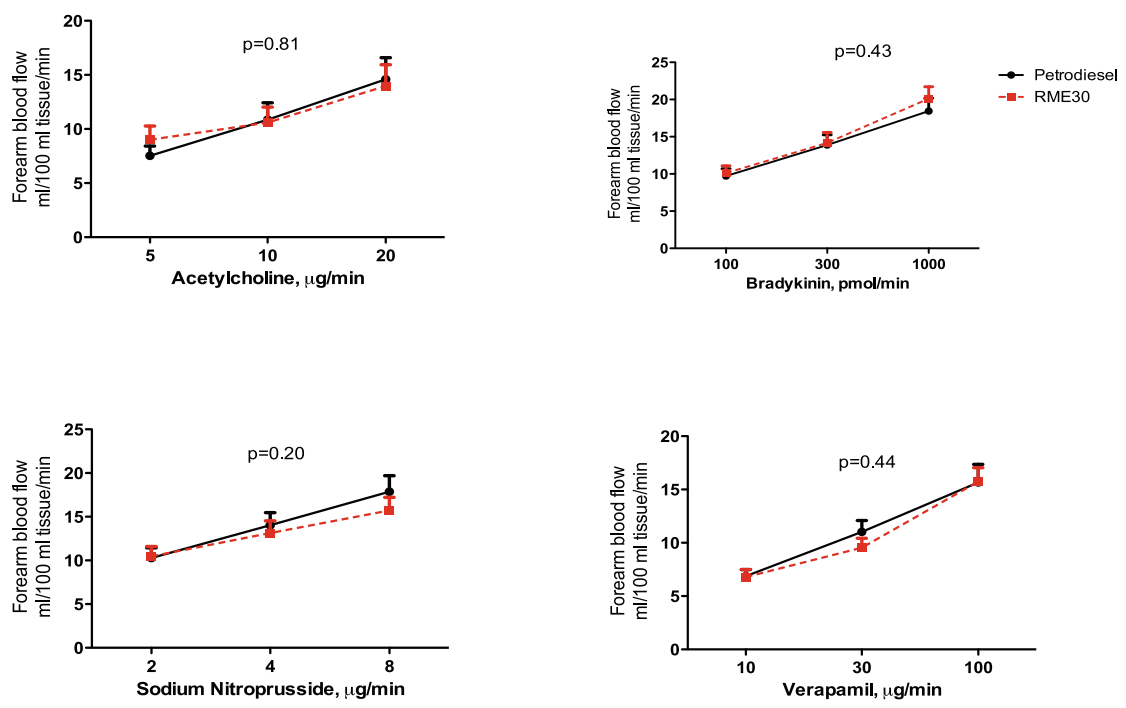

B.
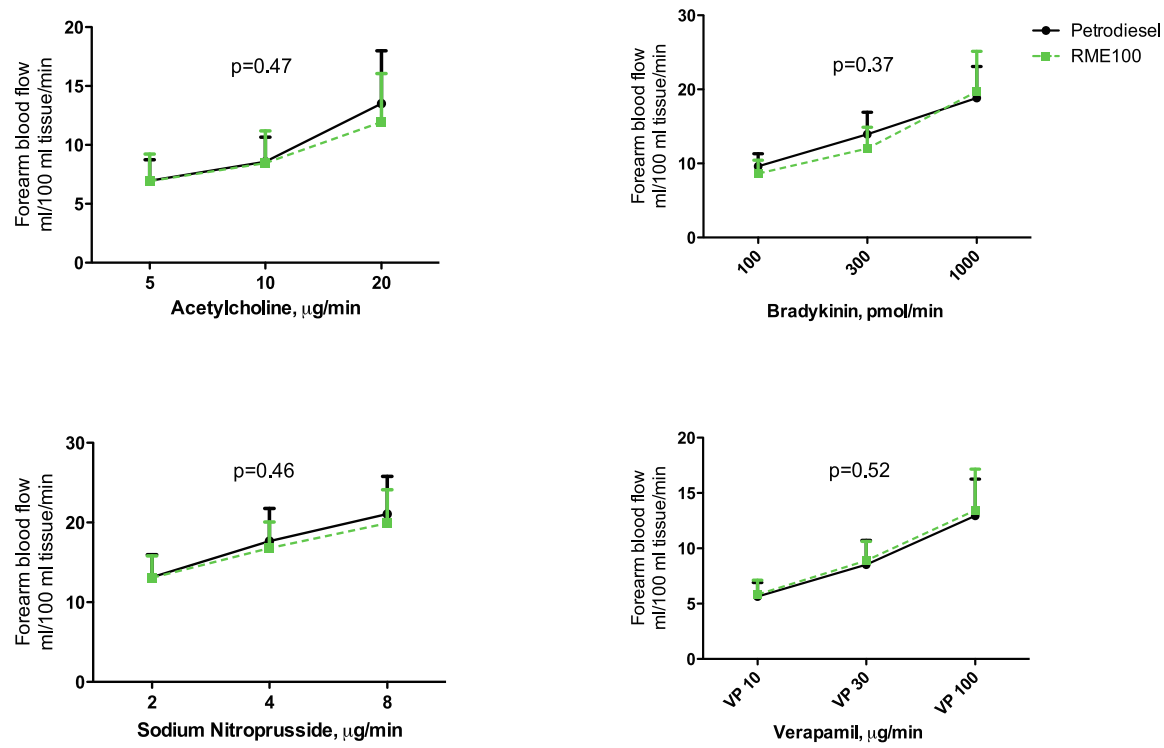

Fig. 3 Forearm blood flow during intrabrachial infusion of vasoactive drugs $4-6 \mathrm{~h}$ post exposure, $\mathrm{mL} / 100 \mathrm{~mL}$ tissue. Mean with $95 \% \mathrm{Cl}$. The graph shows response to incremental doses of acetylcholine, bradykinin, sodium nitroprusside and verapamil following respective exposure. All vasodilators caused an increase in blood flow $(p<0.05$ for all) that was similar between exhaust exposures $(p>0.05$ for all). $P$ values in the graph for respective vasodilator response in the infused arm following exposure to RME30 exhaust compared to PDE $(n=15)$ and RME100 exhaust compared to PDE $(n=18)$, 2-way ANOVA

impairment of vasomotor function along with increased blood thrombogenicity and platelet activation $[7,8,23-$ 27]. In Fig. S1 we display the clear and consistent vasomotor dysfunction caused by exposure to PDE vs. filtered air based on pooled data from four historical studies using similar set ups [23-26]. Performing experimental studies with a three arm design with exposures, canulations and infusions is logistically and practically very difficult to perform, according to our experiences [26]. We therefore decided not to replicate the wellestablished vasomotor effects of PDE exhaust vs. filtered air (Fig. S1), but prioritized a direct comparison of the effects of PDE exhaust with RME biodiesel exhaust, in subjects exposed in the same facility and assessed by 


Fig. 4 Ex vivo thrombosis formation in a model of acute arterial injury. Individual data points for mean thrombus area for each individual, line for
group mean with 95\% Cl. There were no significant differences between RME30 and PDE (study one) or RME100 and PDE (study two) RME30 vs.
PDE $p=0.37, n=13$ and RME100 vs. PDE $p=0.48, n=19$. P values from paired Student's t-test

similar methods as previously. In contrast to vascular and thrombotic measures, our previous studies showed only modest and variable effects on secondary endpoints such as systemic inflammatory responses in terms of blood cells, soluble markers of inflammation and exhaled NO. By using an identical exposure setup and study design as in our previous experimental exposure studies, we have, for the first time, been able to show that replacing petrodiesel with RME30, or RME100, does not substantially alter the vascular response compared to exposure to conventional PDE exhaust. Cardiovascular outcomes (blood flow responses and thrombus formation) were similar for PDE and RME30 under exposure conditions that generated similar particle mass concentrations and, for PDE and RME100, when emission factors were held constant. Thus, these findings imply that the emissions from the RME employed would have comparable adverse effects on cardiovascular health as conventional PDE.

Biodiesel differs from petrodiesel in chemical composition, as it consists mainly of fatty acid methyl esters, whereas petrodiesel mainly contains saturated aliphatic hydrocarbons and aromatics. This gives biodiesel a higher cetane number, meaning it ignites faster [33]. It has also an increased ratio of oxygen, which lowers
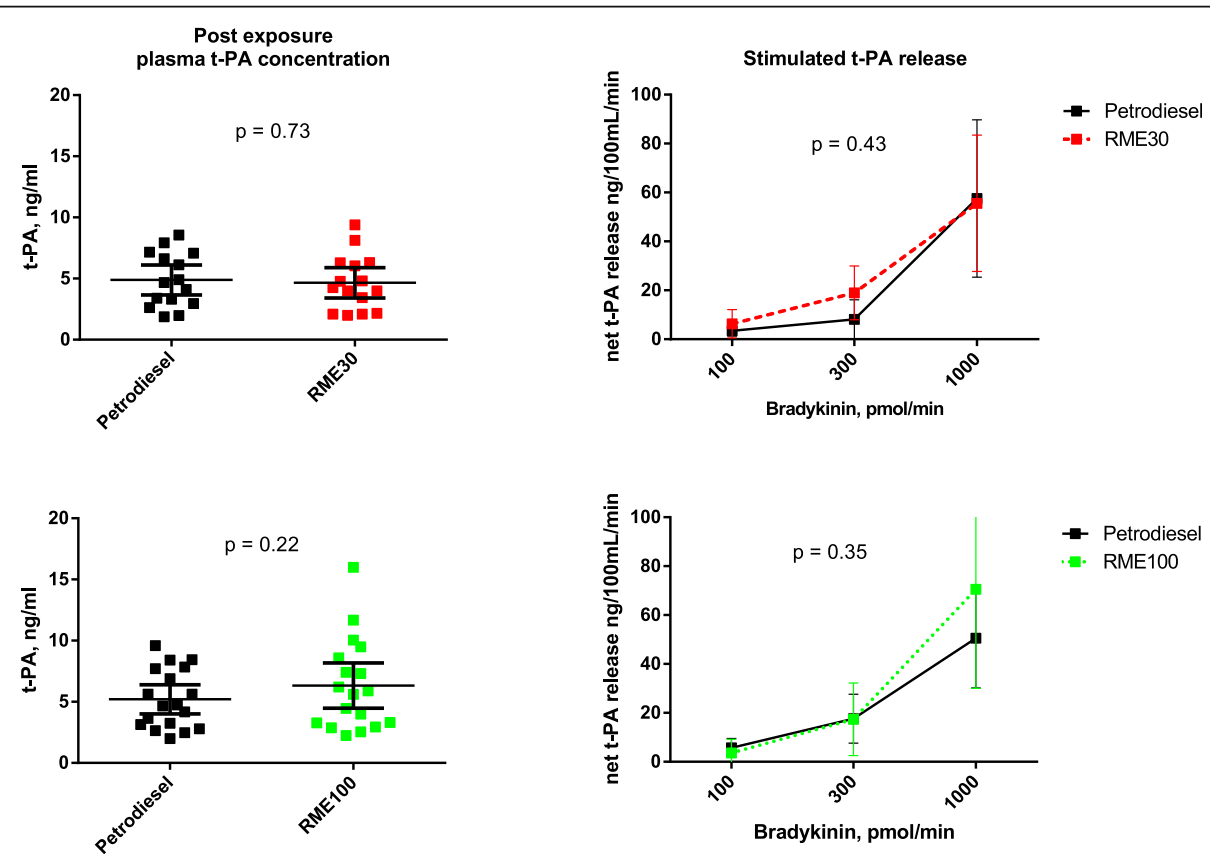

Fig. 5 Mean plasma t-PA antigen concentrations after exposure to petrodiesel vs. RME 30 (upper left panel) and petrodiesel vs. RME100 (lower left panel) were not significantly different between exposures ( $p=0.73$ and $p=0.22$, respectively). Stimulated release of t-PA plasma antigen concentrations following incremental doses of bradykinin infusions, expressed as nanogram per $100 \mathrm{~mL}$ tissue per minute, mean with $95 \% \mathrm{Cl}$ (upper and lower right panels). Bradykinin infusions caused dose dependent increases in t-PA antigen concentrations that were significant at $p<$ 0.01 level for all exposures; petrodiesel and RME 30 (upper right panel) as well as petrodiesel and RME 100 (lower right panel) by 2-way ANOVA. The bradykinin stimulated increases in t-PA did not differ between petrodiesel or RME exposures $(p=0.43$ and $p=0.35$, respectively). 
energy density and, at the same time, increases oxygen content in the ignited fuel spray. Increased oxygen content (which reduces soot formation) together with lower content of aromatics (soot precursors) and sulfur act together to decrease particulate emissions from biodiesel compared to petrodiesel [33]. Consistent with our findings, previous studies have demonstrated that increased biodiesel content in blends with petrodiesel fuel, is associated with reduced PM mass and increased NOx [20, $34,35]$. In addition, previous studies have indicated that addition of biodiesel to conventional petrodiesel fuel is associated with reduced $\mathrm{CO}$ emissions and a higher organic fraction and, in contrast to the present study, reduced hydrocarbons [36]. In RME30, exhaust concentrations of PM-bound PAHs were considerably lower compared to petrodiesel, in line with previous studies [37].

We suggest that it is unlikely that the minor differences in gaseous components, such as $\mathrm{NO}_{\mathrm{x}}$, would play a significant role eliciting the acute cardiovascular effects, as previous exposure studies of the gaseous components alone, or of pure $\mathrm{NO}_{2}$ at similar concentrations, did not result in any acute cardiovascular impairment $[26,27,38]$.

In the present study, the substitution of petrodiesel with a $100 \%$ RME formulation.

reduced the PM mass concentration when emission factors were held constant, but slightly increased the particle number concentration, along with a shift in the size distribution towards the ultrafine range $(<100 \mathrm{~nm})$. We demonstrated a shift from a mono-modal distribution with a peak around 100-140 nm for the PDE exposures to a bi-modal distribution with one peak around $80-90 \mathrm{~nm}$ and a second larger peak around $30-40 \mathrm{~nm}$ during the RME100 exposures. In previous studies, there has been some inconsistency when it comes to size distribution of PM in biodiesel exhaust compared to PDE. Several reports support a similar shift towards smaller particles and an increase in total particle number in RME exhaust [34, 39-41], whereas others have found decreased particle number concentrations [42]. It has been suggested that the ultrafine $(<100 \mathrm{~nm})$ mode of RME exhaust may be composed either of organic matter from RME fuel residues or production constituents with high boiling points, such as triglycerides and glycerol, or of inorganic fuel constituents and/or impurities such as alkali metals, metalloids and trace metals, which may act as condensation nuclei for condensable organics [41]. From our results, it is not possible to draw any conclusions regarding the composition of the different particle size modes. Though, still the subject of debate, it has been proposed that PM in the ultrafine range may be a major contributor to the adverse health effects following inhalation, due to greater surface area relative to mass of PM and higher deposition in the alveoli [43, 44]. In relation to health effects, particle size remains a complex issue, which is yet to be resolved and it remains speculative to suggest to what extent the shift in particle size influenced any endpoints in the current studies.

In our study, we found the oxidative potential of PM from RME exhaust to be lower than that of PM from PDE. Others have suggested RME-derived PM to have similar, or less, oxidative potential than petrodiesel exhaust [45], whilst soy-derived biodiesel PM may have increased oxidative potential (measured as dithiothreitol consumption) compared to petrodiesel-derived PM on a per mass basis [46]. This inconsistency may reflect that biodiesel exhaust in general, and particle properties in particular, is highly variable due to different fuel sources, formulations, storage conditions and combustion properties and engine conditions [13, 47, 48].

Oxidative stress is thought to be a key underlying mechanism driving inflammation following PM exposure $[3,44,49]$. We demonstrated a mild transient systemic inflammation, in terms of increased neutrophil counts, that was similar following all exposures over the observation period. In a study investigating the relative toxicity of PM from different fuels on mouse macrophages, Jalava et al. reported dose-dependent inflammation responses that were similar, or slightly smaller, for RME compared to petrodiesel-derived PM. This trend was stronger with catalytic after-treatment of the exhaust, or when the emission factor was taken into account, as RME produced less PM [45]. Oxidative stress can also result in DNA damage and, in previous in vitro studies, RME-derived PM has been shown to increase mutagenicity and cytotoxicity $[42,48,50]$ compared to PDE. Complementary techniques, such as omics approaches, have potential to elucidate mechanism further, but were not included in this study [51]. Cell based techniques may also further delineate the complexity of the oxidative processes.

In this study, we aimed to assess the cardiovascular effects of biodiesel/biodiesel blend, as an alternative fuel to petrodiesel. Given the aim and that the findings of diesel exhaust-induced endothelial dysfunction, in terms of blunted vasomotor function and impaired endogenous fibrinolysis, together with increased ex vivo thrombus formation, are highly reproducible and consistent in a long series of studies [7-9, 23-27], we did not include a filtered air exposure. The addition of an air exposure would also have added substantially to the complexity of the study, demanding exposures and invasive vascular investigations, three times in each participant. While there at present is no directly comparable controlled exposure study in human subjects investigating detailed biodiesel-induced cardiovascular endpoints, the study by Mehus and coworkers provides some opportunities for comparisons [52]. That study was performed in a mining 
environment and compared health endpoints in human subjects from a pre-exposure day with measurements carried out in the aftermath of two separate exposures to PDE and to a biodiesel blend (75\% soybean methyl ester (SME) with 25\% PDE). The data indicated slightly reduced lung function, increased inflammatory markers in peripheral blood and induced sputum, which did not differ between the petrodiesel and SME 75\% biodiesel exhaust exposures [20]. No filtered air exposure day was included, reflecting the complexity of performing exposure studies of health effects in human volunteers.

\section{Limitations of the study}

The study was not gender balanced, which means the findings cannot be inferred to be applicable in females as well. Our series of earlier studies has, however, not indicated any sex related differences in the vascular response to diesel exhaust.

It is also recognized that subjects with pre-existing disease such as cardiovascular or respiratory diseases have not been studied and could potentially be a more sensitive and reactive population. The subjects were only studied after one single exposure, whereas in real life repeat exposures could potentially elicit enhanced responses. Respiratory effects were addressed to a limited extent in this study and should be explored in more detail in further studies. These aspects all warrant further research into health effects of exhaust from renewable engine fuels in different settings and groups.

\section{Conclusion}

In healthy subjects, exhausts from the two biodiesel formulations RME30 and RME100 were not shown to have significantly different effects on any investigated marker of vascular function or thrombus formation compared to PDE, despite contrasting physico-chemical properties. We suggest that replacing petrodiesel with RME30 or RME100 does not alleviate acute cardiovascular impairment following exhaust inhalation, even in light of reduced PM mass. Whilst there are potential environmental benefits of introducing biofuels, the effects on human health should be a strong consideration when the future use of alternative fuels are determined.

\section{Methods}

The study assessed the acute vascular and thrombotic effects of replacing petrodiesel with a $30 \%$ or $100 \%$ rapeseed biodiesel formulation, following controlled exposure in healthy human subjects. It was hypothesized that inhalation of exhaust from biodiesel formulations would induce less vascular effects compared to standard petrodiesel fuel.

\section{Study design}

Two separate randomized controlled double-blind crossover studies were conducted. In study one, 16 subjects (14 male) were exposed both to PDE and exhaust generated from a biodiesel blend of 30\% RME and 70\% petrodiesel (RME30) on separate occasions. For females, the exposures were carried out in the same phase of the menstrual cycle. In study two, 19 subjects (all male) were separately exposed both to exhaust from 100\% RME biodiesel without blending with petrodiesel (RME100) and PDE. In both studies, exposures were allocated in random order at least one week apart. Exposures were blinded for the subjects and researchers involved, but known to the engineer running the exposure facility from an adjacent room. Investigators were unblinded to the exposure codes only after completion of the full statistical analyses.

Exposures lasted one hour with intermittent exercise on a bicycle ergometer for $15 \mathrm{~min}$ alternating with 15 min rest. The bicycle ergometer was calibrated to give a minute ventilation during exercise of $20 \mathrm{~L} / \mathrm{m}^{2}$ body surface area, as determined during a pre-test day. Exposures were conducted at the same time in the mornings in a purpose-built human exposure chamber, as described previously [23]. Study 1 was performed April-June with an interval of 7-50 days (mean 20 days) between exposures and study 2 September-December with a 7-46day interval (mean 39 days). Subjects were not allowed to take any medication, supplemental vitamins or antioxidants during the week before and during the study and instructed to take a light low nitrate breakfast on exposure days, but otherwise to maintain their normal diet. At mid-day, subjects were given a standardized snack consisting of a protein drink and a piece of fruit. No other food or drink other than water was allowed during the measurements.

\section{Study population}

Thirty-six healthy subjects ( 34 men and 2 women, aged 20-38 years, mean 27 years) were recruited, according to Good Clinical Practice (GCP) principles and as approved by the regional ethical review board and the study was performed in accordance with the Declaration of Helsinki, with the written informed consent from all participants. All volunteers were never regular smokers. A history of limited occasional social smoking was allowed, but not within the last 6 months. They underwent a physician interview and physical examinations and were determined to have normal physiologic parameters, body mass index (BMI), lung function, blood chemistry and electrocardiogram, according to the normal values of the hospital. Exclusion criteria were diabetes mellitus, cardiovascular disease, asthma, smoking or snus usage (powdered tobacco used orally). Female 
subjects took a urinary pregnancy test before each exposure to exclude pregnancy and subjects currently using birth control were excluded. The subjects were all healthy without any current disease or prescribed medication, including non-steroidal anti-inflammatory drugs (NSAID). All were instructed to maintain their normal diet, with no major changes, or additional intake of antioxidant rich components. The imbalance of sex in the study was unintentional and depending on responses to participate in the study: As a consequence, study data are mainly related to male gender.

\section{Exhaust exposure}

RME100 biodiesel and low-sulfur standard diesel (petrodiesel) were acquired from Preem AB (Stockholm, Sweden). RME30 was blended on site using RME100 and petrodiesel. The RME30 contained the proprietary fuel additive ACP (Active Cleaning Power) according to instructions from the fuel company. The additive has been indicated to improve combustion and decrease engine deposits and is intended to be commercially available. The exact chemical composition is confidential, however, Preem $\mathrm{AB}$ has disclosed it to consist of detergent, lubricant and cetane-number improving agents, given as personal information to a lead engineer at the SMP engineering site running the engine set up.

Exhaust was generated using a Volvo diesel engine (Volvo TD40 GJE, 4.0 L, 4 cylinders) running under variable load, according to the urban part of the European Transient Cycle [25]. This engine represents an older generation of diesel engines, that are still widely used, as these engines are extremely durable with slow turnover time from a global perspective. More than $90 \%$ of the exhaust was shunted away and the remainder was mixed with filtered air and fed into the exposure chamber to generate a target $\mathrm{PM}_{10}$ (PM with a mean aerodynamic diameter of $<10 \mu \mathrm{m})$ concentration of $300 \mu \mathrm{g} / \mathrm{m}^{3}$ for both PDE and RME30 [28]. For the RME100 exposure, an identical driving cycle was used with the same load and rounds per minute (rpm) pattern, without modifications to the engine, exhaust dilution system or exposure chamber. The study was specifically designed to investigate the health effects of the exhaust from a specific vehicle when replacing PDE with RME under the same driving conditions rather than similar PM mass concentration in the chamber for the exposures.

\section{Emission characterization}

$\mathrm{PM}_{10}$ concentration was determined gravimetrically using PTFE filters (Pall Teflo Life Science $47 \mathrm{~mm}, 2 \mu \mathrm{m}$ ). Real-time measurement of $\mathrm{PM}_{10}$ with a tapered-element oscillating microbalance (Rupprecht \& Patashnik, Albany, New York, USA) was used during exposures to achieve steady PM levels at $300 \mu \mathrm{g} / \mathrm{m}^{3}$ [25]. A scanning mobility particle sizer system (SMPS TSI, Shoreview, Minnesota, USA) was used to determine fine particle number concentration and size distribution (18-638 $\mathrm{nm})$, which included an electrostatic classifier platform (TSI 3080, TSI GmbH) with a Differential Mobility Analyzer (TSI DMA 3081) and an ultrafine Condensation Particle Counter (TSI CPC 3025A). In addition, PM was also sampled by a Dekati Gravimetric Impactor (DGI) for subsequent analysis of metals and oxidative potential. The DGI classifies particle size according to aerodynamic diameter (cut-points; 2.5, 1.0, 0.5 and $0.2 \mu \mathrm{m}) .47 \mathrm{~mm}$ PTFE plates were used as impactor substrates and $70 \mathrm{~mm}$ PTFE filters as back-up filters (< $0.2 \mu \mathrm{m}$ ). Exposure concentrations were kept as constant as possible and samples were collected at intervals to reflect the average exposure scenarios.

For the carbon fractionation, standard $47 \mathrm{~mm}$ tissue quartz filters and $47 \mathrm{~mm}$ PTFE membrane filters were used. The analysis of particulate carbon fractions was performed by a standard thermal-optical method to determine the content of organic carbon (OC) and elemental carbon (EC) applying the EUSAAR 2 thermal protocol and a thermal-optical carbon analyzer (Sunset Laboratory Inc., Portland, Oregon, USA).

\section{Assessment of metal content in exhaust particulate}

Metal content was assessed using an ELAN DRC ICPMS (MSF008). The three last stages of the DGI sampler were used, i.e. filters; $\mathrm{PM}_{<0.2}, \mathrm{PM}_{0.2-0.5}$ and $\mathrm{PM}_{0.5-1} \mu \mathrm{m}$ and the extraction was performed in HPLC-grade methanol, followed by vortexing and sonication in a water bath (max power, Clifton SW12h, Nickel-Electro Ltd., Weston-super-Mare, UK). The removed filter was then rinsed in methanol. Particle extract was subsequently dried down under nitrogen and recovered mass determined. Mass recoveries for the $\mathrm{PM}_{<0.2}$ and $\mathrm{PM}_{0.2-}$ $0.5 \mu \mathrm{m}$ filters were good; $84.0 \pm 21.3 \%$ (filter loadings ranging from 510 to $860 \mu \mathrm{g}$ ) and $113.0 \pm 38.7 \%$ (170$370 \mu \mathrm{g})$ respectively. Recoveries from the $\mathrm{PM}_{0.5-1.0} \mu \mathrm{m}$ filters were poor, reflecting the low filter loadings (20$180 \mu \mathrm{g})$ and were not used for subsequent analysis. Following particle resuspension in $1.0 \mathrm{~mL}$ of Chelex resintreated water (sonication at max power), $100 \mu \mathrm{L}$ aliquots were added to dilute Aqua Regia, spiked with an internal standard containing $1 \mathrm{ppm}$ indium (isotope 115), gallium (69), bismuth (209) and yttrium (89), sealed in Teflon vessels and placed in a $90^{\circ} \mathrm{C}$ water bath. The mixture was cooled prior to the addition of Chelex-resin treated water. Metals quantified were: aluminum [26], arsenic (75), barium (135), beryllium [9], manganese [53], vanadium [51], antimony (121), cadmium (111), chromium [54], copper (63), molybdenum (95), nickel (60), lead (208), zinc (66), strontium (88), calcium [45], iron (56), boron [11], cobalt (59), rubidium (85), cesium (133), 
gold (197). Elemental concentrations were determined with reference to a 6-point standard curve based on an ICP multi element standard solution VI CertiPUR ${ }^{\circ}$ (Merck, Lot. No. OC529648) or, where not present, in the multi-elemental standard the elements own standard curve (ICP standard, MERCK).

\section{Measurement of PAHs in exhaust}

For collection of particulate and semi-volatile PAHs, sampling with $47 \mathrm{~mm}$ glass fiber filters followed by 70 $\mathrm{mm}$ polyurethane foam plugs (PUFs) were performed in the chamber during the exposures. Both filters and polyurethane foam plugs (PUFs) were spiked with an isotope labeled internal standard mixture. The samples were extracted with pressurized liquid extraction using an ASE 200 Accelerated Solvent Extractor system (Dionex Corporation, Sunnyvale, CA, USA). PUFs were extracted using hexane at $100^{\circ} \mathrm{C}$ and $1100 \mathrm{psi}(7.58 \mathrm{MPa})$. Particles were extracted with toluene/methanol 9:1 (v/v) at $200{ }^{\circ} \mathrm{C}$ and $3000 \mathrm{psi}(20.7 \mathrm{MPa})$.

The raw extracts were concentrated to approximately $0.5 \mathrm{~mL}$ followed by solid phase extraction (SPE), and the SPE-purified extracts were analyzed using an in-house built HPLC-GC-MS system [54]. Data were acquired and processed using MSD ChemStation (Agilent Technologies, Santa Clara, California, USA). PAHs were quantified using single point calibration. Compound identity was determined through compound specific mass to change ratio and its relative retention time on the GC capillary column.

Reported concentrations of semi-volatile PAHs are the sum of; phenanthrene, anthracene, 3-methylphenanthrene, 2-methylphenanthrene, 2-methylanthracene, 9-methylphenanthrene, 1-methylphenanthrene, $4 H$-cyclopenta [def] phenanthrene, 2-phenylnaphthalene, 3,6-dimethylphenanthrene, 3,9-dimethylphenanthrene, fluoranthene, pyrene, 2methylpyrene, 4-methylpyrene, 1-methylpyrene, benz $[a]$ anthracene, and chrysene. Reported concentrations of PM associated PAHs include those measured in the semivolatile phase and the sum of benzo $[b]$ fluoranthene, benzo $[k]$ fluoranthene, benzo $[e]$ pyrene, benzo $[a]$ pyrene, perylene, indeno $[1,2,3-c d]$ pyrene, and benzo [ghi]perylene.

\section{Assessing oxidative potential of PM}

Oxidative potential of PM was first determined by electron paramagnetic resonance (EPR; or electron spin resonance) by measuring oxidation of a spin-trap with preferential selectivity for superoxide free radicals [55]. Briefly, $47 \mathrm{~mm}$ teflon filters with PM were suspended in a physiological saline solution (Krebs buffer) at a particle concentration of $100 \mu \mathrm{g} / \mathrm{mL}$ Samples were vortexed, followed by sonication (100\% power; Fisherbrand FB11002; Fisher Scientific, Loughborough, UK). Suspensions were incubated with the spin-trap, Tempone-H (1 mM; Enzo Life Sciences, Exeter, UK), for $60 \mathrm{~min}$ before measurement. Pyrogallol $(100 \mu \mathrm{M})$, a spontaneous generator or superoxide radicals, was used as a positive control. An X-band EPR spectrometer (Magnettech MS-200, Berlin, Germany) was used. Baseline signals from blank filters were subtracted from that of filters with particulate.

Oxidative potential of PM was also determined by measuring glutathione levels in a synthetic respiratory tract lining fluid (sRTLF) following in vitro exposure to PM. Extracted PM $(50 \mu \mathrm{g} / \mathrm{mL})$ was incubated in sRTLF containing physiologically relevant concentrations of urate (UA), ascorbate (AA) and glutathione (GSH), adjusted to $\mathrm{pH} 7.0$ and incubated at $37^{\circ} \mathrm{C}$ for four hours. Samples were centrifuged to remove particles, prior to samples acidification with metaphosphoric acid (final concentration $5 \% \mathrm{w} / \mathrm{v})$. The remaining concentrations of ascorbate and urate were quantified using reverse phase HPLC with electrochemical detection (Jones Chromatography, Hengoed, Wales). Glutathione concentrations were determined with the GSSG-reductase-5,5'-dithiobis(2-nitrobenzoic acid) (DNTB) recycling assay. Full details of the methodology and derivation of the OP metrics have been described previously $[53,56]$.

\section{Ex vivo blood coagulability model}

Ex vivo thrombus formation was assessed two hours post-exposure using a Badimon chamber perfusion model of acute arterial injury as described previously [8]. In brief, a venous cannula is inserted into an antecubital vein and blood drawn using a peristaltic pump at a rate of $10 \mathrm{~mL} / \mathrm{s}$ via tubing connected to a perfusion chamber submerged in a water bath at $37^{\circ} \mathrm{C}$. This model of acute arterial injury consists of three consecutive chambers containing porcine aortic strips from which the intima is removed, to exposure a prothrombotic surface that simulates deep arterial injury following plaque rupture. Blood is passed through the chambers for five minutes, followed by rinsing with saline. The strips are removed, fixed in paraformaldehyde, embedded for histological analysis, then cut and stained with Masson's trichrome. The sections are analyzed using a semi-automatic microscope and total thrombus area quantified [8].

\section{Vascular endothelial function}

Vascular vasomotor function was assessed using forearm venous occlusion plethysmography four to six hours after each exposure, as described previously [23-25, 27]. The brachial artery was cannulated with a 27 -standardwire-gauge steel needle. Following a saline infusion, four vasodilator drugs, reflecting NO-dependent and nonNO-dependent (verapamil) vasodilation, were infused separately at $1 \mathrm{~mL} / \mathrm{min}$ in incremental doses separated by washouts to restore baseline flow. Bradykinin (100, 300 and $1000 \mathrm{pmol} / \mathrm{min}) ;$ acetylcholine (5, 10 and $20 \mu \mathrm{g} /$ min); sodium nitroprusside (2, 4 and $8 \mu \mathrm{g} / \mathrm{min}$ ) were 
infused in random order, and verapamil (10, 30 and $100 \mu \mathrm{g} / \mathrm{min}$ ) was infused last due to its long acting effects. Mercury-in-silicone strain gauges were used to assess forearm blood flow in both arms (infused arm and non-infused arm) simultaneously. Bradykinin induces the release of the fibrinolytic mediator, tissue plasminogen activator ( $t-\mathrm{PA}$ ) from the vascular endothelium. $\mathrm{t}$ PA antigen concentrations were determined in blood samples collected before the first and following each dose of bradykinin, using enzyme-linked immunosorbent assay (TintElize tPA, Biopool EIA, Trinity Biotech, Bray, Ireland).

\section{Blood cell counts}

Venous blood samples for blood cell counts were obtained pre-exposure and 2, 4, 8 and $24 \mathrm{~h}$ post-exposure and analyzed at an accredited hospital laboratory.

\section{Assessing platelet activation with flow cytometry}

Platelet activation was assessed using flow cytometry at 2 and $4 \mathrm{~h}$ post-exposure. Whole blood samples were immediately labeled with monoclonal antibodies (mAbs) for flow cytometric analysis: CD14-conjugated phycoerythrin (PE) (DAKO, Glostrup, Denmark) specific for monocytes, fluorescein isothiocyanate (FITC)-conjugated CD42a (Serotec, Oxford, UK) specific for platelets and isotype-matched control (Serotec, Oxford, UK). CD14FITC and CD40-PE (Serotec, Oxford, UK) were used for analysis of CD40 positive monocytes. After incubation, cells were fixed and lysed with FACS-Lyse solution (Becton Dickinson, Franklin Lakes, New Jersey, USA) and samples were analyzed using Facs Calibur flow cytometer (Becton Dickinson, Franklin Lakes, New Jersey, USA). Platelet-monocyte aggregation and CD40 positivity of monocytes were expressed as percentage of 20002500 collected monocytes. In addition, to determine platelet surface expression of P-selectin and CD40ligand, whole blood was labeled with CD42a (FITC), CD62p (PE) specific for P-selectin, CD154 specific for CD40 Ligand and isotype controls. Cells were analyzed with a Facs Calibur flow cytometer. Expression of Pselectin and CD40L were expressed as percentage of collected number of platelets (7500).

\section{Respiratory measures}

Forced expiratory volume during first second $\left(\mathrm{FEV}_{1}\right)$ and vital capacity (VC) were measured at baseline and $8 \mathrm{~h}$ postexposure by spirometry (Jaeger Masterlab, Carefusion, San Diego, California) according to ATS/ERS guidelines (56). Fraction of exhaled $\mathrm{NO}\left(\mathrm{FE}_{\mathrm{NO}}\right)$ concentrations were evaluated using a nitric oxide analyzer $\left(\mathrm{NIOX}^{\circ}\right.$, Aerocrine $\mathrm{AB}$, Stockholm, Sweden) at an exhalation rate of $50 \mathrm{~mL} / \mathrm{s}( \pm$ $10 \%), \mathrm{FE}_{\mathrm{NO}} 50$. Lung function measurements post-exposure were performed at $8 \mathrm{~h}$ based on findings from preceding studies as well as logistic aspects. As vascular measurements were prioritized in the current study lung function was mainly included to rule out major respiratory effects.

\section{Data analysis and statistics}

Based on our previous studies of endothelial vasomotor function and endogenous fibrinolysis, to detect a $20 \%$ difference in forearm blood flow and a $16 \%$ difference in t-PA release, we require sample sizes of $n=16$ at $80 \%$ power and two-sided $P<0.05$. Statistical analyses were performed with GraphPad Prism (version 5, GraphPad Software, La Jolla, California, USA). Data were analyzed using paired and unpaired Student's t-test, Wilcoxon signed rank test and repeated measures analysis of variance (ANOVA), as appropriate. For blood cell counts, post-exposure changes from baseline were calculated at individual level. Statistical significance was taken at 2sided $p<0.05$.

\section{Abbreviations \\ ACP: Active Cleaning Power; CAPS: concentrated ambient particles; EC/OC ratio: elemental carbon/organic carbon ratio; EPR: electron paramagnetic resonance; $\mathrm{FE}_{\mathrm{NO}} 50$ : Fraction of exhaled nitric oxide at $50 \mathrm{~L} / \mathrm{min}$ flow; OPAA: oxidative potential for ascorbic acid; $\mathrm{OP}^{\mathrm{GSH}}$ : oxidative potential for glutathione; OP ${ }^{\text {TOT: }}$ total oxidative potential; PAHs: Polyaromatic \\ hydrocarbons; PDE: 100\% petrodiesel fuel exhaust; PM: Particulate matter; $\mathrm{PM}_{10}$ : PM with a mean aerodynamic diameter of $<10 \mu \mathrm{m} ; \mathrm{PM}_{2.5}$ : PM with a mean aerodynamic diameter of < $2.5 \mu \mathrm{m}$; RME 30: Rapeseed methyl ester $30 \%$ blended diesel fuel; RME 100: Rapeseed methyl ester 100\% exhaust}

\section{Supplementary Information}

The online version contains supplementary material available at https://doi. org/10.1186/s12989-021-00412-3.

\section{Additional file 1.}

Additional file 2.

\section{Acknowledgements}

We would like to thank the research subjects involved and the nursing staff at the Department of Medicine, University Hospital, Umeå for invaluable assistance. Thanks also to technical staff at Svensk Maskinprovning, Umeå, Sweden, for expertise in designing and running the exposure facility, as well as Edwin Carter and Callam Davidson at the University of Edinburgh for their contributions (tPA and EPR analysis respectively). The valuable contributions of Dr. Jeremy Langrish and Dr. Andrew Lucking is acknowledged.

\section{Authors' contributions}

$J A B, J U, C B, I S M, N L M, D E N, A B$, TS and conceived and designed the experiments. JAB, JU, RN, MK contributed to material sampling. JAB, JU, RN, $M K, I S, E P, J R, M R M$ contributed to analyses and data processing. JAB, JU, MK contributed to the analysis of the data set. JAB, JU, CB, RW, ISM, ML, AB, TS drafted the paper. All authors read and approved the manuscript.

\section{Funding}

This work was supported by the Swedish Heart Lung Foundation, the Swedish Clean Air Research Program, AFA-insurances, Sweden, Umeå University, Västerbotten County Council and a British Heart Foundation programme grant (RG/10/9/28286), Stockholm University and the Swedish Strategic Vehicle Research and Innovation (FFI). NLM was supported by a British Heart Foundation Senior Clinical Research Fellowship (FS/16/ 14/32023) and MRM is supported by a British Heart Foundation Special Project Grant (SP/15/8/31575). DEN is supported by the British Heart Foundation (CH/09/002) and is the recipient of a Welcome Trust Senior 
Investigator Award (WT103782AIA). Open Access funding provided by Umea University.

\section{Availability of data and materials}

All relevant data are included in the manuscript and supporting information. These are also available from the authors upon reasonable request.

\section{Declarations}

\section{Ethics approval and consent to participate}

The study was approved by the local ethics committee at Umeå University and all participants gave their written informed consent to participate.

\section{Consent for publication}

Not applicable.

\section{Competing interests}

The authors report no competing financial or other interests.

\section{Author details}

'Department of Public Health and Clinical Medicine, Section of Medicine, Umeå University, Umeå, Sweden. ${ }^{2}$ Department of Surgical Sciences, Uppsala University, Uppsala, Sweden. ${ }^{3}$ Thermochemical Energy Conversion Laboratory, Umeå University, Umeå, Sweden. ${ }^{4}$ Department of Materials and Environmental Chemistry, Stockholm University, Stockholm, Sweden. ${ }^{5}$ MRC-PHE Centre for Environment and Health, NIHR Health Protection Research Unit in Environmental Exposures and Health, Imperial College London, London, UK. ${ }^{6}$ Centre for Inflammation Research, University of Edinburgh, Edinburgh, UK. ${ }^{7}$ University/BHF Centre for Cardiovascular Science, University of Edinburgh, Edinburgh, UK. ${ }^{8}$ Usher Institute of Population Health Sciences and Informatics, University of Edinburgh, Edinburgh, UK. ${ }^{9}$ Dept. of Medicine, Division of Respiratory Med, University Hospital, 90185 Umeå, Sweden.

Received: 10 June 2020 Accepted: 4 May 2021

Published online: 14 June 2021

\section{References}

1. Pope CA 3rd, Ezzati M, Dockery DW. Fine-particulate air pollution and life expectancy in the United States. N Engl J Med. 2009;360(4):376-86. https:// doi.org/10.1056/NEJMsa0805646.

2. Beelen $R$, Hoek G, Raaschou-Nielsen O, Stafoggia M, Andersen ZJ, Weinmayr $\mathrm{G}$, et al. Natural-cause mortality and long-term exposure to particle components: an analysis of 19 European cohorts within the multi-center ESCAPE project. Environ Health Perspect. 2015;123(6):525-33.

3. Riediker M, Zink D, Kreyling W, Oberdörster G, Elder A, Graham U, et al. Particle toxicology and health - where are we? Part Fibre Toxicol. 2019; 16(1):1.

4. Laden F, Neas LM, Dockery DW, Schwartz J. Association of fine particulate matter from different sources with daily mortality in six U.S. cities. Environ Health Perspect. 2000;108(10):941-7. https://doi.org/10.1289/ehp.00108941.

5. Zheng M, Cass GR, Lin K, Wang F, Schauer JJ, Edgerton ES, et al. Source apportionment of daily fine particulate matter at Jefferson street, Atlanta, GA, during summer and winter. J Air Waste Management Assoc. 2007;57(2): 228-42. https://doi.org/10.1080/10473289.2007.10465322.

6. Peters A, Von Klot S, Heier M, Trentinaglia I, Hörmann A, Wichmann HE, et al. Exposure to traffic and the onset of myocardial infarction. $N$ Engl J Med. 2004:351(17):1721-30. https://doi.org/10.1056/NEJMoa040203.

7. Mills NL, Tornqvist H, Gonzalez MC, Vink E, Robinson SD, Soderberg S, et al Ischemic and thrombotic effects of dilute diesel-exhaust inhalation in men with coronary heart disease. N Engl J Med. 2007;357(11):1075-82. https:// doi.org/10.1056/NEJMoa066314

8. Lucking AJ, Lundbäck M, Mills NL, Faratian D, Barath SL, Pourazar J, et al. Diesel exhaust inhalation increases thrombus formation in man. Eur Heart J. 2008;29(24):3043-51. https://doi.org/10.1093/eurhearti/ehn464.

9. Lundbäck M, Mills NL, Lucking A, Barath S, Donaldson K, Newby DE, et al. Experimental exposure to diesel exhaust increases arterial stiffness in man. Part Fibre Toxicol. 2009;6(1):7. https://doi.org/10.1186/1743-8977-6-7.

10. Langrish JP, Bosson J, Unosson J, Muala A, Newby DE, Mills NL, et al. Cardiovascular effects of particulate air pollution exposure: time course and underlying mechanisms. J Intern Med. 2012;272(3):224-39. https://doi.org/1 0.1111/j.1365-2796.2012.02566.x.

11. https://www.eduskunta.fi/SV/vaski/EduskunnanVastaus/Sidor/RSv_228+201 8.aspx (accessed 14 April 2020).

12. Robbins M. Policy: fuelling politics. Nature. 2011;474(7352):S22-4. https://doi. org/10.1038/474S022a

13. Singh D, Sharma D, Soni SL, Sharma S, Sharma PK, Jhalani. A review on feedstocks, production processes, and yield for different generations of biodiesel. Fuel. 2020;262:116553.

14. Graboski MS, Mccormick RL. Combustion of fat and vegetable oil derived fuels in diesel engines. Prog Energy Combust Sci. 1998;24:125-64.

15. Graboski MS, McCormick RL. Combustion of fat and vegetable oil derived fuels in diesel engines. Prog Energy Combust Sci. 1998;24(2):125-64.

16. Madden MC. A paler shade of green? The toxicology of biodiesel emissions: Recent findings from studies with this alternative fuel. Biochim Biophys Acta. 2016;1860(12):2856-62.

17. Godri Pollitt KJ, Chhan D, Rais K, Pan K, Wallace JS. Biodiesel fuels: A greener diesel? A review from a health perspective. Sci Total Environ. 2019;688:103655.

18. Vaughan A, Stevanovic S, Banks APW, Zare A, Rahman MM, Bowman RV, Fong KM, Ristovski ZD, Yang IA. The cytotoxic, inflammatory and oxidative potential of coconut oil-substituted diesel emissions on bronchial epithelial cells at an air-liquid interface. Environ Sci Pollut Res Int. 2019;26:27783-91.

19. Jalava PI, Aakko-Saksa P, Murtonen T, Happo MS, Markkanen A, Yli-Pirilä P, Hakulinen P, Hillamo R, Mäki-Paakkanen J, Salonen RO, Jokiniemi J, Hirvonen MR. Toxicological properties of emission particles from heavy duty engines powered by conventional and bio-based diesel fuels and compressed natural gas. Part Fibre Toxicol. 2012;9:37.

20. Magnusson P, Oczkowski M, Øvrevik J, Gajewska M, Wilczak J, Biedrzycki J, Dziendzikowska K, Kamola D, Królikowski T, Kruszewski M, Lankoff A, Mruk R, Brunborg G, Instanes C, Gromadzka-Ostrowska J, Myhre O. No adverse lung effects of 7- and 28-day inhalation exposure of rats to emissions from petrodiesel fuelcontaining 20\% rapeseed methyl esters (B20) with and without particulate filter - the FuelHealth project. Inhal Toxicol. 2017;29:20618.

21. Newby DE, Wright RA, Labinjoh C, Ludlam CA, Fox KA, Boon NA, et al. Endothelial dysfunction, impaired endogenous fibrinolysis, and cigarette smoking: a mechanism for arterial thrombosis and myocardial infarction. Circulation. 1999;99(11):1411-5. https://doi.org/10.1161/01.CIR.99.11.1411.

22. Mills NL, Törnqvist H, Robinson SD, Gonzalez M, Darnley K, MacNee W, et al. Diesel exhaust inhalation causes vascular dysfunction and impaired endogenous fibrinolysis. Circulation. 2005;112(25):3930-6. https://doi.org/1 0.1161/CIRCULATIONAHA.105.588962.

23. Törnqvist H, Mills NL, Gonzalez M, Miller MR, Robinson SD, Megson IL, et al. Persistent endothelial dysfunction in humans after diesel exhaust inhalation. Am J Respir Crit Care Med. 2007;176(4):395-400. https://doi.org/10.1164/ rccm.200606-8720C

24. Barath S, Mills NL, Lundbäck M, Törnqvist H, Lucking AJ, Langrish JP, et al. Impaired vascular function after exposure to diesel exhaust generated at urban transient running conditions. Part Fibre Toxicol. 2010;7:19.

25. Mills NL, Miller MR, Lucking AJ, Beveridge J, Flint L, Boere AJ, et al. Combustion-derived nanoparticulate induces the adverse vascular effects of diesel exhaust inhalation. Eur Heart J. 2011;32(21):2660-71. https://doi.org/1 0.1093/eurheartj/ehr195.

26. Rudell B, Blomberg A, Helleday R, Ledin MC, Lundbäck B, Stjernberg N, et al. Bronchoalveolar inflammation after exposure to diesel exhaust: comparison between unfiltered and particle trap filtered exhaust. Occup Environ Med. 1999;56(8):527-34. https://doi.org/10.1136/oem.56.8.527.

27. Lucking AJ, Lundbäck M, Barath SL, Mills NL, Sidhu MK, Langrish JP, et al. Particle traps prevent adverse vascular and prothrombotic effects of diesel engine exhaust inhalation in men. Circulation. 2011;123(16):1721-8. https:// doi.org/10.1161/CIRCULATIONAHA.110.987263.

28. Salvi S, Blomberg A, Rudell B, Kelly F, Sandström T, Holgate ST, et al. Acute inflammatory responses in the airways and peripheral blood after short-term exposure to diesel exhaust in healthy human volunteers. Am J Respir Crit Care Med. 1999:159(3):702-9. https://doi.org/10.1164/ajrccm.159.3.9709083.

29. Bosson J, Pourazar J, Forsberg B, Adelroth E, Sandström T, Blomberg A. Ozone enhances the airway inflammation initiated by diesel exhaust. Respir Med. 2007;101(6):1140-6. https://doi.org/10.1016/j.rmed.2006.11.010.

30. Behndig AF, Larsson N, Brown JL, Stenfors N, Helleday R, Duggan ST, et al. Proinflammatory doses of diesel exhaust in healthy subjects fail to elicit 
equivalent or augmented airway inflammation in subjects with asthma. Thorax. 2011;66(1):12-9. https://doi.org/10.1136/thx.2010.140053.

31. Brook RD, Brook JR, Urch B, Vincent R, Rajagopalan S, Silverman F. Inhalation of fine particulate air pollution and ozone causes acute arterial vasoconstriction in healthy adults. Circulation. 2002;105(13):1534-6. https://doi.org/10.1161/01.CIR.0000013838.94747.64.

32. Giakoumis EG, Rakopoulos CD, Dimaratos AM, Rakopoulos DC. Exhaust emissions of diesel engines operating under transient conditions with biodiesel fuel blends. Prog Energy Combust Sci. 2012;38(5):691-715. https://doi.org/10.1016/j.pecs.2012.05.002.

33. Madden MC. A paler shade of green? The toxicology of biodiesel emissions: recent findings from studies with this alternative fuel. Biochim Biophys Acta. 2016;1860(12):2856-62. https://doi.org/10.1016/j.bbagen.2016.05.035.

34. Coufalik P, Matousek T, Krumal K, Vojtisek-Lom M, Beranek V, Mikuska P. Content of metals in emissions from gasoline, diesel, and alternative mixed biofuels. Environ Sci Pollut Res Int. 2019;26(28):29012-9. https://doi.org/10.1 007/s11356-019-06144-4.

35. Nyström R, Sadiktsis I, Ahmed MT, Westerholm R, Koegler JH, Blomberg A, et al. Physical and chemical properties of RME biodiesel exhaust particles without engine modifications. Fuel. 2016;186:261-9. https://doi.org/10.1016/ j.fuel.2016.08.062.

36. Sadiktsis I, Koegler JH, Benham T, Bergvall C, Westerholm R. Particulate associated polycyclic aromatic hydrocarbon exhaust emissions from a portable power generator fueled with three different fuels - A comparison between petroleum diesel and two biodiesels. Fuel. 2014;115:573-80. https://doi.org/10.1016/j.fuel.2013.07.062.

37. Langrish JP, Lundbäck M, Barath S, Söderberg S, Mills NL, Newby DE, et al. Exposure to nitrogen dioxide is not associated with vascular dysfunction in man. Inhal Toxicol. 2010;22(3):192-8. https://doi.org/10.3109/089583 70903144105

38. Tsolakis A. Effects on particle size distribution from the diesel engine operating on RME-biodiesel with EGR. Energy Fuel. 2006;20(4):1418-24. https://doi.org/10.1021/ef050385c.

39. Chuepeng S, Xu H, Tsolakis A, Wyszynski M, Price C. Particulate matter size distribution in the exhaust gas of a modern diesel engine fuelled with a biodiesel blend. Biomass Bioenergy. 2011;35(10):4280-9. https://doi.org/10.1 016/j.biombioe.2011.07.017

40. Heikkilä J, Virtanen A, Rönkkö T, Keskinen J, Aakko-Saksa P, Murtonen T. Nanoparticle emissions from a heavy-duty engine running on alternative diesel fuels. Environ Sci Technol. 2009;43(24):9501-6. https://doi.org/10.1021/ es9013807.

41. Westphal GA, Krahl J, Munack A, Rosenkranz N, Schröder O, Schaak J, et al. Combustion of hydrotreated vegetable oil and jatropha methyl ester in a heavy duty engine: emissions and bacterial mutagenicity. Environ Sci Technol. 2013;47(11):6038-46. https://doi.org/10.1021/es400518d.

42. Donaldson K, Brown D, Clouter A, Duffin R, MacNee W, Renwick L, et al. The pulmonary toxicology of ultrafine particles. J Aerosol Med. 2002;15(2):21320. https://doi.org/10.1089/089426802320282338.

43. Leikauf GD, Kim SH, Jang AS. Mechanisms of ultrafine particle-induced respiratory health effects. Exp Mol Med. 2020;52(3):329-37. https://doi.org/1 0.1038/s12276-020-0394-0.

44. Jalava PI, Tapanainen M, Kuuspalo K, Markkanen A, Hakulinen P, Happo MS, et al. Toxicological effects of emission particles from fossil- and biodieselfueled diesel engine with and without DOC/POC catalytic converter. Inhal Toxicol. 2010;(Suppl 2):48-58.

45. Cheung KL, Polidori A, Ntziachristos L, Tzamkiozis T, Samaras Z, Cassee FR, et al. Chemical characteristics and oxidative potential of particulate matter emissions from gasoline, diesel, and biodiesel cars. Environ Sci Technol. 2009;43(16):6334-40. https://doi.org/10.1021/es900819t.

46. Agarwal KA, Gupta K, Kothari A. Particulate emissions from biodiesel vs diesel fuelled compression ignition engine. Renew Sust Energ Rev. 2011; 15(6):3278-300. https://doi.org/10.1016/j.rser.2011.04.002.

47. Bünger J, Krahl J, Schröder O, Schmidt L, Westphal GA. Potential hazards associated with combustion of bio-derived versus petroleum-derived diesel fuel. Crit Rev Toxicol. 2012;42(9):732-50. https://doi.org/10.3109/10408444.2 012.710194.

48. Miller MR. Oxidative stress and the cardiovascular effects of air pollution. Free Radic Biol Med. 2020;151:69-87. https://doi.org/https://doi.org/10.1016/j. freeradbiomed.2020.01.004.

49. Liu Y-Y, Lin T-C, Wang Y-J, Ho W-L. Carbonyl compounds and toxicity assessments of emissions from a diesel engine running on biodiesels. J Air
Waste Manage Assoc. 2009;59(2):163-71. https://doi.org/10.3155/1047-3289. 59.2.163.

50. Selley L, Phillips DH, Mudway I. The potential of omics approaches to elucidate mechanisms of biodiesel-induced pulmonary toxicity. Part Fibre Toxicol. 2019;16(1):4. https://doi.org/10.1186/s12989-018-0284-y.

51. Mehus AA, Reed RJ, Lee VS, Littau SR, Hu C, Lutz EA, et al. Comparison of acute health effects from exposures to diesel and biodiesel fuel emissions. J Occup Environ Med. 2015;57(7):705-12. https://doi.org/10.1097/JOM. 0000000000000473.

52. Christensen A, Ostman C, Westerholm R. Ultrasound-assisted extraction and on-line Ic-gc-ms for determination of polycyclic aromatic hydrocarbons (pah) in urban dust and diesel particulate matter. Anal Bioanal Chem. 2005; 381(6):1206-16. https://doi.org/10.1007/s00216-005-3065-z.

53. Miller MR, Hankinson J, Brusasco V, Burgos F, Casaburi R, Coates A, et al. Standardisation of spirometry. Eur Respir J. 2005;26(2):319-38. https://doi. org/10.1183/09031936.05.00034805.

54. Miller MR, Borthwick SJ, Shaw CA, McLean SG, McClure D, Mills NL, et al. Direct impairment of vascular function by diesel exhaust particulate through reduced bioavailability of endothelium-derived nitric oxide induced by superoxide free radicals. Environ Health Perspect. 2009;117(4):611-6. https://doi.org/10.1289/ehp.0800235.

55. Godri KJ, Duggan ST, Fuller GW, Baker T, Green D, Kelly FJ, et al. Particulate matter oxidative potential from waste transfer station activity. Environ Health Perspect. 2010;118(4):493-8. https://doi.org/10.1289/ehp.0901303.

56. Godri KJ, Harrison RM, Evans T, Baker T, Dunster C, Mudway IS, et al. Increased oxidative burden associated with traffic component of ambient particulate matter at roadside and urban background schools sites in London. PLoS One. 2011;6(7):e21961. https://doi.org/10.1371/journal.pone. 0021961.

\section{Publisher's Note}

Springer Nature remains neutral with regard to jurisdictional claims in published maps and institutional affiliations.
Ready to submit your research? Choose BMC and benefit from:

- fast, convenient online submission

- thorough peer review by experienced researchers in your field

- rapid publication on acceptance

- support for research data, including large and complex data types

- gold Open Access which fosters wider collaboration and increased citations

- maximum visibility for your research: over $100 \mathrm{M}$ website views per year

At BMC, research is always in progress.

Learn more biomedcentral.com/submissions 